\title{
The impact of C2C Communication and Shared Information on Buying Decision: "A Buyer's Perspective"
}

\author{
Jamshida KV, B. Rajeswari
}

\begin{abstract}
C2C e-commerce has been gradually more utilized by consumers to buy and sell goods prominently nowadays. With this increase in usage a need for detailed studies regarding $C 2 C$ e-commerce has been created. The information shared among the buyers of C2C ecommerce plays a vital role in consumer's purchase behavior along with other factors. The present study aims to find out the impact of shared information and communication among $\mathrm{C2C}$ online consumers on making purchase decisions. Based on 290 effective respondents, the TAM model is used to find out the respondent's online purchase intention is influenced by shared communication along with perceived risk, and trust of the model. SPSS 25 is used to find the regression analysis and correlation analysis to study the impact and influence of the above mentioned variables. The findings show that there is a significant relationship between the electronic word of mouth and purchase intention of consumers which is created through perceived ease of use, and perceived trust. The C2C online models are a successful platform for the users who interested to buy second hand or refurbished products through ecommerce. The study helps to find out whether there is any trustful or risk free purchase is possible if the consumers communicate about the product or services that offered.
\end{abstract}

Keywords: C2C online purchase, Technology Acceptance model, shared information and communication, purchase intention.

\section{INTRODUCTION}

$\mathbf{T}_{1}$ he Consumer-to-Consumer E-Commerce in India, seems to be emerging as a highly profitable model. By comparing to other developed countries, it is just in growth stage and there is a very big scope of future growth. Here, in India the $\mathrm{C} 2 \mathrm{C}$ Platform already exists and now-a-days consumers are widely engaging in these type of transactions because of the wide spread use of Information Technology everywhere. However, the battlefield winners are the leaders in the context of C2C E-Commerce in India, the most leading third party platforms earning around 80 percent market share by the use of $\mathrm{C} 2 \mathrm{C}$ E-Commerce, earlier it was $\mathrm{B} 2 \mathrm{C}$ E-Commerce [1]

The objective of the study is to identify and analyse the factors that influence online purchase intention in $\mathrm{C} 2 \mathrm{C}$ consumer markets and analyse that in which way the

Revised Manuscript Received on July 22, 2019.

Jamshida KV, Department of Management Studies, Pondicherry University, Pondicherry, India. Email: jamshikuruppath@gmail.com

Dr. B. Rajeswari, Department of Management Studies, Pondicherry University, Pondicherry, India. Email: raajeebster@gmail.com communication and shared information between the $\mathrm{C} 2 \mathrm{C}$ consumers through online word of mouth influences the purchase behavior and purchase intention. Consumers who are involved in this section sell their goods and services to the other consumers via a third-party website [2].

\section{LITERATURE REVIEW}

The Technology Acceptance Model (TAM) [4] is considered as one of the most effective model to envisage the consumer's acceptance towards a new technology for commodity purchases. And it has been studied widely in the areas of academics and research [5]. There are a mass number of studies have been done about the use of TAM and consumer's technology acceptance. The TAM is treated as the ultra-efficient tool to test the consumer acceptance as well as the latest technology adoption [6]. The TAM is considered as the advanced and elaborated model of TRA (Theory of Reasoned Action) [7]. One of the important drawbacks of TAM is that it does not discuss about the consumer's variance in the purchase behavior and it deals with very little application in the latest technology adoptions due to its frugality [8].

On the ground of these drawbacks, the study only focuses some of the parts of the constructs of TAM.

The consumer's intention towards to purchase a particular brand is the purchase intention of that consumer [9]. The consumer's purchase decision making is widely depends upon the value that given to that particular products and same as the great influence of social media also [10]. Purchase intention is nothing but the consumer intends to create a relationship with the retailer for communicating business information, building trade related relationships and practicing or exchanging trade transactions [11]. TRA defines purchase intention as a subjective probability of person participating in specific intention, the purpose which is to define the most important factors in purchase intention [12]. The prompt development of internet lead ecommerce as efficient and trustful platform for online purchases, and various studies shows that buyer's attitude for user generated substances on social media and the intention towards the use of user generated substances in buyer's decision making are positive [13]. The positive attitude for a particular brand will significantly influence the consumer's purchase intention also they will be ready to give a high price for that product [14]. Also the consumer's intention or involvement in the ecommerce can be a key predictor of buyer's actual participation in online shopping [15].

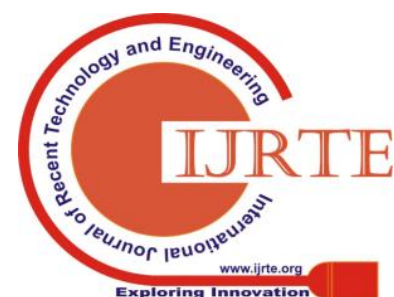


As per the former studies in the areas of TAM application in $\mathrm{C} 2 \mathrm{C}$ ecommerce and online purchases, several factors have been studied and these are involves with purchase intention and attitude of online consumers that are related with the perceived ease of use, usefulness, enjoyment with the online word of mouth of $\mathrm{C} 2 \mathrm{C}$ online models $[6,16,17,18]$.

$\mathrm{C} 2 \mathrm{C}$ communication states that "the sharing of information between one consumer (and a set of consumers) to a new consumer (or a set of consumers) according to the strength, preferential changes, current purchase behaviour, and style of interacting with others".

The online word of mouth is the sharing of information through internet or electronic medium about the product or services sometimes the brands, company etc. $[19,20]$

\section{RESEARCH METHODOLOGY}

To analyse the importance and relevance of each perspective, an empirical study was conducted. The objective of this study is to identify the factors that contribute consumers purchase intention, and then to study the relationship between those factors that affects the intention.

So the objectives of the study will be as follows;

- To analyse whether the consumer's online word of mouth of the website significantly increases the Trust in C2C website adoption.

- To study the role of online word of mouth in $\mathrm{C} 2 \mathrm{C}$ website adoption to reduce the perceived risk in $\mathrm{C} 2 \mathrm{C}$ ecommerce website adoption.

The factors that influence consumer trust and confidentiality to adopt the $\mathrm{C} 2 \mathrm{C}$ website platforms are classified into three main categories; online word of mouth, perceived usefulness, perceived risk, and trust in the purchase intention of $\mathrm{C} 2 \mathrm{C}$ website adoption. The model that tested is shown below;

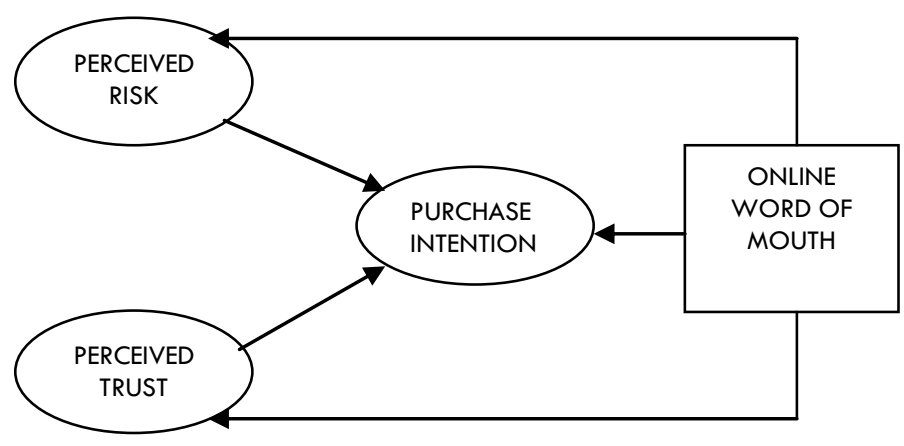

Fig. 1. Research Model

The hypotheses are as follows;

H1: The consumers' online word of mouth of the website positively contributes the trust in $\mathrm{C} 2 \mathrm{C}$ ecommerce website adoption.

$\mathrm{H} 2$ : The consumers' online word of mouth of the website positively contributes the trust in $\mathrm{C} 2 \mathrm{C}$ ecommerce website adoption.

H3: There is no relationship between the online word of mouth of the $\mathrm{C} 2 \mathrm{C}$ websites and purchase of the $\mathrm{C} 2 \mathrm{C}$ websites.

H4: The consumers' Trust in $\mathrm{C} 2 \mathrm{C}$ website adoption positively reduces the Perceived Risk in $\mathrm{C} 2 \mathrm{C}$ ecommerce.

\section{A) Reliability Analysis}

Reliability analysis was applied to analyse and measure the reliability of the entire scale as well as individual items in the scale. Reliability evaluation of the entire scale was first done followed by the individual evaluation of each item. The overall reliability of the entire scale was seemed to be good with a Cronbach's alpha of 0.792 .

The individual construct reliability of the scale was as follows:

Table- I: Cronbach's alpha

\begin{tabular}{|c|c|}
\hline ITEMS & $\begin{array}{c}\text { CRONBACH'S } \\
\text { ALPHA }\end{array}$ \\
\hline Purchase Intention & 0.760 \\
\hline Online Word of Mouth & 0.738 \\
\hline Perceived Risk & 0.825 \\
\hline Perceived Trust & 0.835 \\
\hline
\end{tabular}

\section{B)Regression Analysis}

Linear regression was used to predict the variables. It is used when we want to predict the value of a variable based on the value of another variable. The $R^{2}$ value and $R$ value of the variables were as follows:

Table- I: Cronbach's alpha

\begin{tabular}{|c|c|c|c|}
\hline VARIABLES & PREDICTORS & $\mathrm{R}$ & $\mathrm{R}^{2}$ \\
\hline $\begin{array}{c}\text { Purchase } \\
\text { Intention }\end{array}$ & Perceived Risk & 0.768 & 0.589 \\
\hline $\begin{array}{c}\text { Perceived } \\
\text { Risk }\end{array}$ & $\begin{array}{c}\text { Online word of } \\
\text { mouth }\end{array}$ & 0.935 & 0.874 \\
\hline $\begin{array}{c}\text { Perceived } \\
\text { Trust }\end{array}$ & $\begin{array}{c}\text { Online word of } \\
\text { mouth }\end{array}$ & 0.891 & 0.794 \\
\hline $\begin{array}{c}\text { Purchase } \\
\text { Intention }\end{array}$ & $\begin{array}{c}\text { Online word of } \\
\text { mouth }\end{array}$ & 0.841 & 0.707 \\
\hline
\end{tabular}

\section{C)Correlation Analysis}

The Pearson Correlation Coefficient is a measure of strength and direction of association that exist between two variables measured. Correlation coefficient value of the online word of mouth and purchase intention were tested, as per the results $r$ is 0.603 , and that it is statistically significant $(\mathrm{p}=0.005)$. 


\section{D) Hypothesis Testing}

H1: The consumers' online word of mouth of the website positively contributes the trust in $\mathrm{C} 2 \mathrm{C}$ ecommerce website adoption.

The model helps to predict trust in $\mathrm{C} 2 \mathrm{C}$ website adoption. $\mathrm{R}$ means the correlation between predicted and observed trust in $\mathrm{C} 2 \mathrm{C}$ website adoption. In this case $\mathrm{R}=0.935$. Since, this is a very high correlation; this model predicts the trust in $\mathrm{C} 2 \mathrm{C}$ website adoption. The $\mathrm{R}^{2}$ is nothing but the square $\mathrm{R}$. It shows the proportion of 'variance' in trust in $\mathrm{C} 2 \mathrm{C}$ ecommerce website adoption that can be analysed by the predictor of online word of mouth $\left(\mathrm{R}^{2}=0.874\right)$

H2: The consumer's perceived risk of the website positively contributes the purchase intention in $\mathrm{C} 2 \mathrm{C}$ ecommerce website adoption.

It indicates the $\mathrm{R}=0.768$ which shows a good correlation and the Perceived Usefulness is a good predictor of Trust in C2C ecommerce website with a $\mathrm{R}^{2}$ of 0.589 .

H3: There is no relationship between the online word of mouth of the $\mathrm{C} 2 \mathrm{C}$ websites and purchase intention of the $\mathrm{C} 2 \mathrm{C}$ websites.

The study shows the result that the relationship is statistically significant with significant level less than $0.01(\mathrm{p}=$ 0.000 ). The $R=0.603$ which is greater than 0.5 and we reject the null hypothesis.

H4: The consumers' electronic word of mouth in $\mathrm{C} 2 \mathrm{C}$ website adoption positively reduces the perceived risk in $\mathrm{C} 2 \mathrm{C}$ ecommerce.

The results shows that $\mathrm{R}=0.891$ which is a good correlation and $\mathrm{R}^{2}=0794$ though the Trust in C2C website adoption is a good predictor of Perceived Risk in website adoption.

\section{CONCLUSION}

In this study it is concluded that the trust online word of mouth or shared information and communication of the third party $\mathrm{C} 2 \mathrm{C}$ website platforms is a relevant factor in describing consumers' risk, trust, and purchase intention upon the $\mathrm{C} 2 \mathrm{C}$ online transactions. So in earlier researches, risk and privacy seems to be the major factor for consumers' trust in $\mathrm{C} 2 \mathrm{C}$ e-commerce website adoption, the empirical results shows that there is a good correlation between online word of mouth and purchase intention with consumers' trust and risk. This may be because consumers' wide usage of Internet and social media which tend them to communicate and share their concerns about a particular product or service that an internet system offers. However, the model of perceived risk and trust evidences itself primarily through online word of mouth in C2C website adoption. As trust and confidentiality of consumers depend upon the heart of continuing $\mathrm{C} 2 \mathrm{C}$ e-commerce relationship, web-based platforms need to find paths for improving consumers' perception of their trust and confidentiality in order to utilize fully the potential of $\mathrm{C} 2 \mathrm{C}$ e-commerce. Overall, the consumer's information sharing and communication in $\mathrm{C} 2 \mathrm{C}$ website adoption leads a customer to purchase the product or service in a positive way.

\section{REFERENCES}

1. Sekulovska, M. (2012) Business Models for E-Insurance and Conditions in Republic of Macedonia. Procedia-Social and Behavioral Sciences, 44, 163-168. http://dx.doi.org/10.1016/j.sbspro.2012.05.016

2. Liao, C.C., To, P.-L. and Shih, M.-L. (2006) Website Practices: A Comparison between the Top 1000 Companies

3. Hong, D., Ping, Y., \& Jun, J. (2016). Telematics and Informatics Understanding the influence of $\mathrm{C} 2 \mathrm{C}$ communication on purchase decision in online communities from a perspective of information adoption model. TELEMATICS AND INFORMATICS, 33(1), 8-16. http://doi.org/10.1016/j.tele.2015.06.001

4. Taherdoost, H. (2018). Development of an adoption model to assess user acceptance of e-service technology: E-Servive Technology Acceptance Model. Behaviour and Information Technology, 37(2), doi:10.1080/0144929x.2018.1427793

5. Ayeh JK. (2015). Travellers' acceptance of consumer-generated media: An integrated model of technology acceptance and source credibility theories. Computers in Human Behavior. 48:173-180. DOI:https://doi.org/10.1016/j.chb.2014.12.0 49.

6. Fishbein M. (1976). A theory of reasoned action: Some applications and implications. Nebraska Symposium on Motivation. 27:65-116

7. Cunha LK, Mandapaka PV, Krajewski WF, Mantilla R, Bradley AA (2012). Impact of radar rainfall error structure on estimated flood magnitude across scales: An investigation based on a parsimonious distributed hydrological model. Water Resources Research. 48(10):1-22. DOI:https://doi.org/10.1029/2012WR

8. Lucas Jr. HC, Swanson EB, Zmud RW. (2008). Implementation, innovation, and related themes over the years in information systems research. Journal of the Associate for Information Systems. 8(4):2016210

9. Zeithaml V. (1998). Consumer perceptions of price, quality and value A means-end model and synthesis of evidence. Journal of Marketing. 52(3):2-22

10. Davis FD. (1998). Perceived usefulness, perceived ease of use, and user acceptance of information technology. MIS Quarterly. 13(3):319-340

11. Lopez M, Sicilia M .(2014). Determinants of EWOM influence: the role of consumers' internet experience. Journal of Theoretical and Applied Electronic Commerce Research. 9(1):28-43

12. Shah SSH, Aziz J, Jaffari A, Waris S, Ejaz W, Fatima M, Sherazi SK (2012). The impact of brands on consumer purchase intentions. Asian Journal of Business Management. 4(2):105-110

13. Fu, S., Yan, Q., and Feng, G. C. (2018). Who will attract you? Similarity effect among users on online purchase intention of movie tickets in the social shopping context. International Journal of Information Management. 40:88-102

14. Agag G., El-Masry AA (2016). Understanding consumer intention to participate in online travel community and effects on consumer intention to purchase travel online and WOM: An integration of innovation diffusion theory and TAM with trust. Computers in human behavior, 60, 97-111. doi:10.1016/j.chb.2016.02.038

15. Lien CH, Cao Y (2014). Examining WeChat users' motivations, trust, attitudes, and positive word of mouth: Evidence from China. Computers in human behavior. 41:104-111

16. Davis FD, Bagozzi RP, Warshaw PR (1992). Extrinsic and intrinsic motivation to use computers in the workplace. Journal of Applied social psychology. 22(14):1081-1159

17. Liu X, Wei KK (2003). An empirical study of product differences in consumers' ecommerce adoption behavior. Electronic Commerce Research and Applications. 2(3):229-239

18. Bearden WO, Etzel MJ. (1982). Reference group influence on product and brand purchase decisions. Journal of Consumer Research. 9(2):183-194

19. Lohse GL, Spiller P. (1998). Electronic shopping: Designing online stores with effective customer interfaces has a critical influence on traffic and sales. Communications of the ACM, 41(7):81-88

20. Yoon, S. (2002). The antecedents and consequences of trust in online purchase decisions. Journal of Interactive Marketing, 16(2), 47-63.doi:10.1002/dir.1000 


\section{AUTHORS PROFILE}

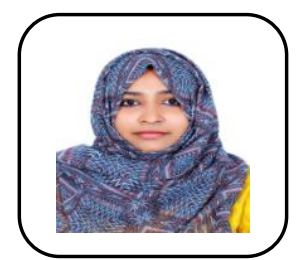

Jamshida KV is a PhD scholar in Pondicherry University, India. She got her Master in Business Administration (Human Resource and Finance) from Calicut University, India and Master in Commerce (Finance) from Pondicherry University. She got her Bachelor in Business Administration (Marketing) from Calicut University, India. In addition she has a Diploma in Foreign Trade (International Business) from Pondicherry University, India.

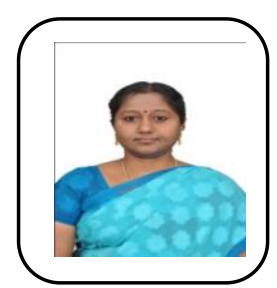

Dr.B. Rajeswari, Assistant Professor, Marketing and Operations, Department of Management Studies, Pondicherry University, India. More than 10 years of teaching experience. Placement co coordinator, research guide and organizer of conferences and workshops. 